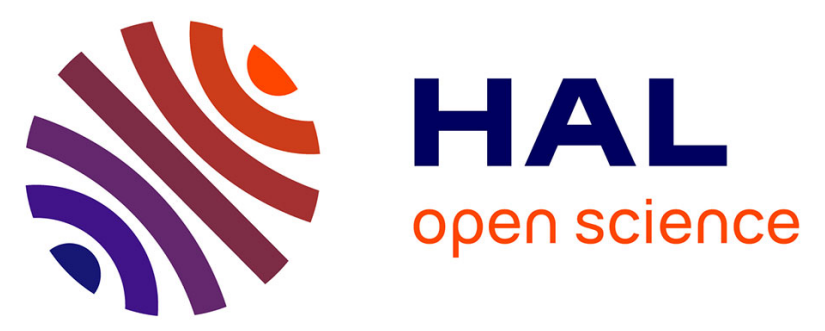

\title{
Interference by atrazine and bisphenol A with progestin binding to the ovarian progestin membrane receptor and induction of oocyte maturation in Atlantic croaker
}

Peter Thomas, Jennifer Sweatman

\section{- To cite this version:}

Peter Thomas, Jennifer Sweatman. Interference by atrazine and bisphenol A with progestin binding to the ovarian progestin membrane receptor and induction of oocyte maturation in Atlantic croaker. Marine Environmental Research, 2008, 66 (1), pp.1. 10.1016/j.marenvres.2008.02.005 . hal-00563004

\author{
HAL Id: hal-00563004 \\ https://hal.science/hal-00563004
}

Submitted on 4 Feb 2011

HAL is a multi-disciplinary open access archive for the deposit and dissemination of scientific research documents, whether they are published or not. The documents may come from teaching and research institutions in France or abroad, or from public or private research centers.
L'archive ouverte pluridisciplinaire $\mathbf{H A L}$, est destinée au dépôt et à la diffusion de documents scientifiques de niveau recherche, publiés ou non, émanant des établissements d'enseignement et de recherche français ou étrangers, des laboratoires publics ou privés. 


\section{Accepted Manuscript}

Interference by atrazine and bisphenol A with progestin binding to the ovarian progestin membrane receptor and induction of oocyte maturation in Atlantic croaker

Peter Thomas, Jennifer Sweatman

PII: $\quad$ S0141-1136(08)00021-4

DOI: $\quad 10.1016 /$ j.marenvres.2008.02.005

Reference: $\quad$ MERE 3173

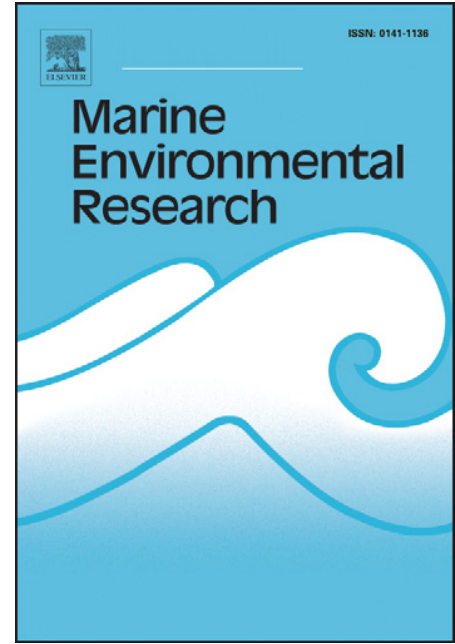

To appear in:

Marine Environmental Research

Please cite this article as: Thomas, P., Sweatman, J., Interference by atrazine and bisphenol A with progestin binding to the ovarian progestin membrane receptor and induction of oocyte maturation in Atlantic croaker, Marine Environmental Research (2008), doi: 10.1016/j.marenvres.2008.02.005

This is a PDF file of an unedited manuscript that has been accepted for publication. As a service to our customers we are providing this early version of the manuscript. The manuscript will undergo copyediting, typesetting, and review of the resulting proof before it is published in its final form. Please note that during the production process errors may be discovered which could affect the content, and all legal disclaimers that apply to the journal pertain. 


\title{
Interference by atrazine and bisphenol A with progestin binding to
}

\section{the ovarian progestin membrane receptor and induction of oocyte}

\author{
maturation in Atlantic croaker
}

Peter Thomas *, Jennifer Sweatman

University of Texas at Austin, Marine Science Institute, 750 Channel View Drive,Port Aransas, TX 78373, U.S.A.

\begin{abstract}
Recent studies have shown that several environmental chemicals which disrupt classical genomic steroid actions can also interfere with nongenomic steroid actions initiated at the cell surface. The effects of bisphenol-A and atrazine on the nongenomic actions of a progestin,

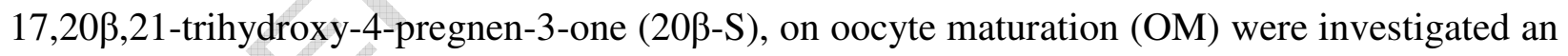

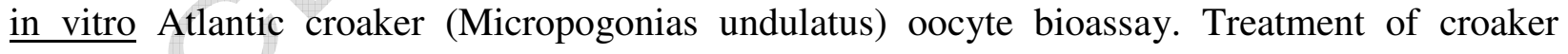
follicle-enclosed oocytes with either bisphenol-A or atrazine blocked OM in response to 20ß-S in a concentration-dependent manner at 10-25 $\mu \mathrm{M}(2.2-5.7 \mathrm{ppm})$ and higher concentrations. These compounds were also effective competitors at concentrations of $10^{-6}$ to $10^{-5} \mathrm{M}$ of $\left[{ }^{3} \mathrm{H}\right]-20 \beta-\mathrm{S}$ binding to the ovarian progestin membrane receptor that mediates the OM response to $20 \beta-\mathrm{S}$. The results suggest that diverse classes of environmental chemicals can disrupt nongenomic progestin actions via receptor-mediated mechanisms.
\end{abstract}


Keywords: Atrazine; Bisphenol-A; Oocyte maturation; Nongenomic endocrine disruption; Progestin membrane receptor; Atlantic croaker

*Corresponding author: Tel: +1-361-749-6788; fax: +1-361-749-6777

E-mail address: thomas@utmsi.utexas.edu (P. Thomas)

In addition to the classic genomic mechanism of steroid action via binding and activation of nuclear steroid receptors, steroids can also act at the cell surface of many target tissues including the brain, pituitary, bone, heart, gonads and gametes to initiate rapid, nongenomic responses mediated by binding to steroid membrane receptors. Recent studies have shown that nongenomic steroid actions, like genomic ones, are susceptible to interference by environmental estrogens and nonestrogenic endocrine disrupting chemicals (EDCs, Ghosh and Thomas, 1999; Nadal et al., 2000; Thomas and Doughty, 2005). In the present study the effects of an estrogenic EDC, bisphenol-A and a nonestrogenic one, atrazine, on progestin induction of oocyte maturation $(\mathrm{OM})$ and binding to the ovarian membrane progestin receptor were investigated in Atlantic croaker. Currently, there is considerable interest and controversy over the mechanisms of action of these two EDCs. Interference with a nongenomic progestin action was investigated in an in vitro oocyte maturation bioassay which determines the percentage of oocytes that undergo germinal vesicle breakdown (GVBD), an easily observable endpoint during oocyte maturation (Ghosh and Thomas, 1995). Fragments of Atlantic croaker ovaries containing 
approximately 100 full grown follicle-enclosed oocytes (diameter $>450 \mu \mathrm{m}$ ) were primed for 8$11 \mathrm{~h}$ with human chorionic gonadotropin $(15 \mathrm{IU} / \mathrm{ml})$ prior to $12 \mathrm{~h}$ treatment with the maturation-

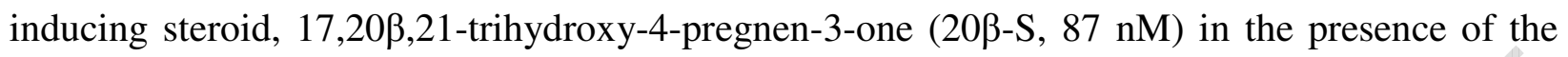
test chemicals (1 -50 $\mu \mathrm{M}$ ). Atrazine ( ChemService, Inc.,Westchester, PA,) and bisphenol-A (City Chemical (Westhaven, CT) were added dissolved in methanol and ethanol, respectively (final conc. $<1 \%$ ). The carrier solvents were also added to the controls treated with $20 \beta-\mathrm{S}$ alone. Atrazine significantly impaired $20 \beta-S$-induced $\mathrm{OM}$ at concentrations of $10 \mu \mathrm{M}$ and above in a dose-dependent manner, with fewer than $10 \%$ of the oocytes maturing at the highest concentration, $50 \mu \mathrm{M}$ (16.4ppm, Fig.1A). The herbicide also significantly impaired maturation of spotted seatrout oocytes in a parallel in vitro bioassay at concentrations of $0.1 \mu \mathrm{M}$ and $1 \mu \mathrm{M}$ (results not shown). Bisphenol-A treatment also decreased OM in response to 20ß-S, although it appeared to be less potent than atrazine, since maturation of croaker oocytes (Fig.1B) and spotted seatrout oocytes (results not shown) was not significantly decreased by concentrations below 25 $\mu \mathrm{M}$.

Possible interactions of these chemicals with the membrane progestin receptor mediating progestin-induced OM was investigated in competitive binding radioreceptor assays (Das and Thomas, 1999). Plasma membrane fractions of ovarian tissues containing full grown oocytes $(>450 \mu \mathrm{m})$ and radiolabelled $20 \beta-\mathrm{S}\left(\left[{ }^{3} \mathrm{H}\right]-20 \beta-\mathrm{S}, 41.9 \mathrm{Ci} / \mathrm{mmol}\right)$ were prepared as described previously (Patino and Thomas, 1990). Competition assays were conducted with $\left.5 \mathrm{nM} \mathrm{[}{ }^{3} \mathrm{H}\right]-20 \beta-$ $\mathrm{S}$ in the presence of different concentrations of the test chemicals (range $1 \mathrm{nM}-10 \mu \mathrm{M}$, dissolved in 1-5 $\mu$ l ethanol, which does not affect ligand binding in the receptor assays). After a 30-min incubation at $4^{\circ} \mathrm{C}$ with the membrane fractions, the reaction was stopped by filtration (Whatman GF/B filters, presoaked in assay buffer), washed, and bound radioactivity was measured by 
scintillation counting. The displacement of the radiolabelled steroid binding by the steroid competitors was expressed as a percentage of the maximum specific binding of the steroid for its receptor. Both atrazine and bisphenol-A were effective competitors of $\left[{ }^{3} \mathrm{H}\right]-20 \beta-\mathrm{S}$ binding to the croaker ovarian membrane progestin receptor, causing significant displacement at a concentration of $10^{-6} \mathrm{M}$ and approximately $50 \%$ displacement at $10^{-5} \mathrm{M}$ (Fig.2). Scatchard binding analyses will be required to determine whether the binding of these compounds to the receptor is competitive (i.e. same binding site as $20-\mathrm{S}$ ). Previous studies suggest Kepone binds competitively to the seatrout ovarian 20 -S receptor (Das and Thomas, 1999), whereas another estrogenic EDC, diethylstilbestrol, binds to a different site on the goldfish ovarian progestin receptor (Tokumoto et al., 2007).

The ovarian $20 \beta-S$ receptor mediating OM has been identified as a novel seventransmembrane receptor, called membrane progestin receptor alpha (mPR $\alpha$, Zhu et al., 2003). Recent studies suggest $\mathrm{mPR} \alpha$ also mediates $20 \beta-\mathrm{S}$ induction of sperm hypermotility in this species (Thomas et al., 2005). It is not surprising, therefore, that atrazine and bisphenol -A are also potent inhibitors of sperm hypermotility in response to $20 \beta-\mathrm{S}$ in croaker (Thomas and Doughty, 2005). Overall, progestin stimulation of sperm motility appears to be much more susceptible to interference by chemicals than OM and is significantly impaired by less then onetenth of the minimum effective concentrations observed in the present study (Thomas and Doughty, 2005). These differences may be due to lower effective concentrations of the test compounds at the oocyte surface than at the sperm membrane because the oocytes are surrounded by follicle cells. Bisphenol-A also binds to GPR30, the novel seven-transmembrane membrane estrogen receptor that has been characterized in breast cancer cells (Thomas et al., 2005), where it exerts an estrogen action (Thomas and Dong, 2006). GPR30 has also been 
identified in croaker ovaries (Pang and Thomas, unpubl.), raising the possibility that this environmental estrogen could influence ovarian and oocyte functions by interfering with estrogen as well as progestin nongenomic actions through interactions with both $\mathrm{mPR} \alpha$ and GPR30.

\section{Acknowledgements}

Supported by NIH grant ESO12961 to P.T. and a McNare Scholarship to J.S.

\section{References}

Das, S., and Thomas, P. (1999). Endocrinology, 140, 1953-1956.

Ghosh, S., and Thomas, P. (1995). Marine Environmental Research, 39,159-163.

Nadal, A., Ropero A.B., Laribi O., Maillet M., Fuentes E., and Soria B. (2000). Proceedings National Academy Science USA, 97, 11603-11608.

Patiño, R., and Thomas,P. (1990). General and Comparative Endocrinology, 78, 204-217.

Thomas, P., and Dong, J. (2006). Journal Steroid Biochemistry and Molecular Biology, 102, 107-109.

Thomas, P., and Doughty, K. (2005). Environmental Science and Technology, 38, 6328-6332.

Thomas, P., Tubbs, C., Detweiler, D., Das, S., Ford, L., and Breckenridge-Miller, D. (2005). Steroids, 70, 427-433.

Tokumoto, T., Tokumoto, M., and Thomas, P. (2007). Endocrinology, 148, 3459-3467. 


\section{ACCEPTED MANUSCRIPT}

Zhu, Y., Rice, C.D., Pang, Y., Pace, M., and Thomas, P. (2003). Proceedings National Academy Science USA, 100, 2231-2236. 


\section{Figure captions}

Fig. 1. Concentration -dependent inhibition by (A) atrazine, and (B) bisphenol-A of 20ß-Sinduced maturation of Atlantic croaker oocytes in an in vitro bioassay. \%GVBD: percent of oocytes that have completed germinal vesicle breakdown. Asterisks denote means significantly different from controls (0), Student's t test, $\mathrm{N}=4$.

Fig. 2. Competition by atrazine and bisphenol-A for $\left[{ }^{3} \mathrm{H}\right]-20 \beta-\mathrm{S}$ binding to Atlantic croaker ovarian membranes. 
Figure 1

A

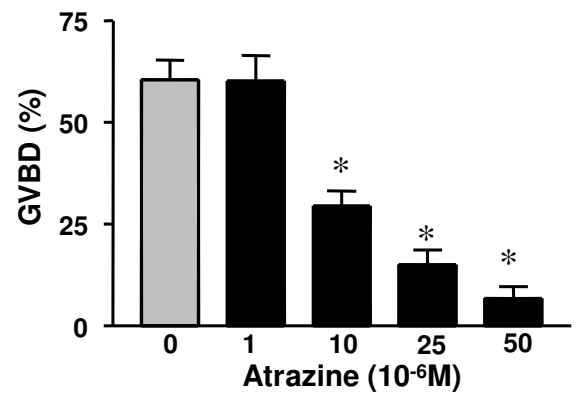

B

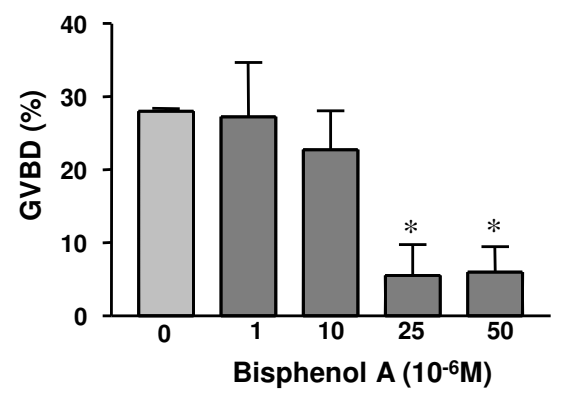


ACCEPTED MANUSCRIPT

Figure 2

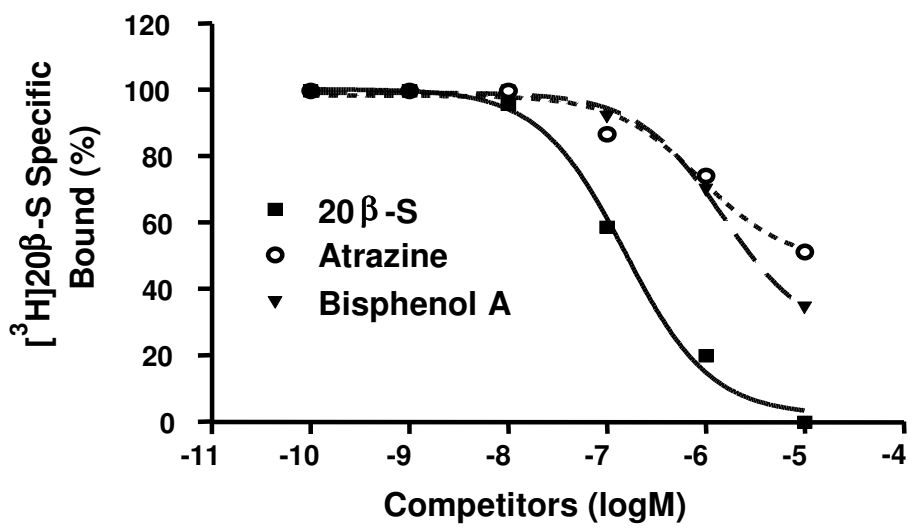

